\title{
Northeastern Atlantic cold-water coral reefs and climate
}

\author{
Norbert Frank ${ }^{1}$, André Freiwald ${ }^{2,3}$, Matthias López Correa ${ }^{3}$, Claudia Wienberg ${ }^{4}$, Markus Eisele ${ }^{4}$, Dierk Hebbeln ${ }^{4}$, David \\ Van Rooij ${ }^{5}$, Jean-Pierre Henriet ${ }^{5}$, Christophe Colin ${ }^{6}$, Tjeerd van Weering ${ }^{7}$, Henk de Haas ${ }^{7}$, Pål Buhl-Mortensen ${ }^{8}$, \\ J. Murray Roberts ${ }^{9}$, Ben De Mol ${ }^{10}$, Eric Douville ${ }^{1}$, Dominique Blamart ${ }^{1}$, and Christine Hatté ${ }^{1}$ \\ 'Laboratoire des Sciences du Climat et de l'Environnement, Institute Pierre Simon Laplace (LSCE/IPSL), Unité Mixte de Recherche, \\ UMR8212, Avenue de la Terrasse, 91198 Gif/Yvette, France \\ 2Senckenberg am Meer, Abteilung Meeresforschung, Südstrand 40, 26382 Wilhelmshaven, Germany \\ ${ }^{3}$ GeoZentrum Nordbayern (GZN), Universität Erlangen-Nürnberg, Loewenichstrasse 28, 91054 Erlangen, Germany \\ ${ }^{4}$ MARUM, Universität Bremen, Leobener Strasse, 28359 Bremen, Germany \\ ${ }^{5}$ Renard Centre of Marine Geology (RCMG), Ghent University, Krijgslaan 281 S8, 9000 Gent, Belgium \\ 'Laboratoire IDES (Interactions et Dynamique des Environnements de Surface), Unité Mixte de Recherche, UMR 8148, Université \\ de Paris-Sud, 91405 Orsay, France \\ ${ }^{7}$ Royal Netherlands Institute for Sea Research (NIOZ), Landsdiep 4, 1797 SZ, 't Horntje (Texel), Netherlands \\ ${ }^{8}$ Institute of Marine Research, PO Box 1870 Nordnes, 5024 Bergen, Norway \\ ${ }^{9}$ Centre for Marine Biodiversity \& Biotechnology, School of Life Sciences, Heriot-Watt University, Edinburgh, Scotland EH14 4AS, UK \\ ${ }^{10}$ Grup de Recerca Geociències Marines, Parc Científic de Barcelona, Adolf Florensa 8, 08028 Barcelona, Spain
}

\section{ABSTRACT}

U-series age patterns obtained on reef framework-forming cold-water corals collected over a nearly 6000-km-long continental margin sector, extending from off Mauritania $\left(17^{\circ} \mathrm{N}\right.$; northwest Africa) to the southwestern Barents Sea $\left(70^{\circ} \mathrm{N}\right.$; northeastern Europe), reveal strong climate influences on the geographical distribution and sustained development of these ecosystems. Over the past three glacial-interglacial cycles, framework-forming cold-water corals (Lophelia pertusa and Madrepora oculata) seem to have predominantly populated reefs, canyons, and patches in the temperate East Atlantic and the Mediterranean Sea. Above $50^{\circ} \mathrm{N}$ corals colonize reefs in the northern East Atlantic primarily during warm climate periods with the biogeographic limit advancing from $\sim 50^{\circ} \mathrm{N}$ to $\sim 70^{\circ} \mathrm{N}$. We propose that north-south oscillations of the biogeographic limit of reef developments are paced by ice ages and may occur synchronously with north-south displacement of cold nutrient-rich intermediate waters and surface productivity related to changes of the polar front.
Active reefs are situated in mid-depth (500 $1200 \mathrm{~m}$ depth) water masses originating in the Subpolar Gyre and Subtropical Gyre underneath the Eastern North Atlantic Water (Fig. 1A). As far north as the Porcupine Seabight, corals occur close to the upper depth limit of northward-moving Mediterranean Sea water. Farther north, reefs are found along the Norwegian margin in North Atlantic Current water, underneath the low saline surface waters of the Norwegian Coastal Current. The cold-water coral ecosystems abruptly disappear off Sørøya (Barents Sea, $70^{\circ} \mathrm{N}, 23^{\circ} \mathrm{E}$ ), which reflects today's northern biogeographic

\section{INTRODUCTION}

In the northern East Atlantic, cold-water coral ecosystems forming reefs (Roberts et al., 2009) are actively growing in 600-900 $\mathrm{m}$ water depths north of $50^{\circ} \mathrm{N}$, in some places on giant coral carbonate mounds around Porcupine, Rockall, and Hatton Banks and Porcupine Seabight (Roberts et al., 2009). The depth of active cold-water coral reef development shallows to $<400 \mathrm{~m}$ on the Norwegian margin, which today harbors the greatest number of individual cold-water coral reefs in the world (Freiwald, 2002). These modern northern cold-water coral reefs support stunningly dense live coral populations and high local biodiversity (Roberts et al., 2006). The most important environmental forcing factors favoring contemporary cold-water coral growth are the advection of labile organic carbon (Davies et al., 2009) and the presence of enhanced near-bed currents (White and Dorschel, 2010) with temperatures of $4{ }^{\circ} \mathrm{C}$ to $12{ }^{\circ} \mathrm{C}$ (Roberts et al., 2009). Moreover, coral larvae need hard substrates to settle, and for the Nordic and Celtic margins it has been shown that active reefs are situated in water masses with a potential density, $\sigma_{\theta}$, close to 27.5 (Dullo et al., 2008). Overall, reefs are situated in water masses of $2.6-7.2 \mathrm{ml} \mathrm{L}^{-1}$ dissolved oxygen (Davies et al., 2008).
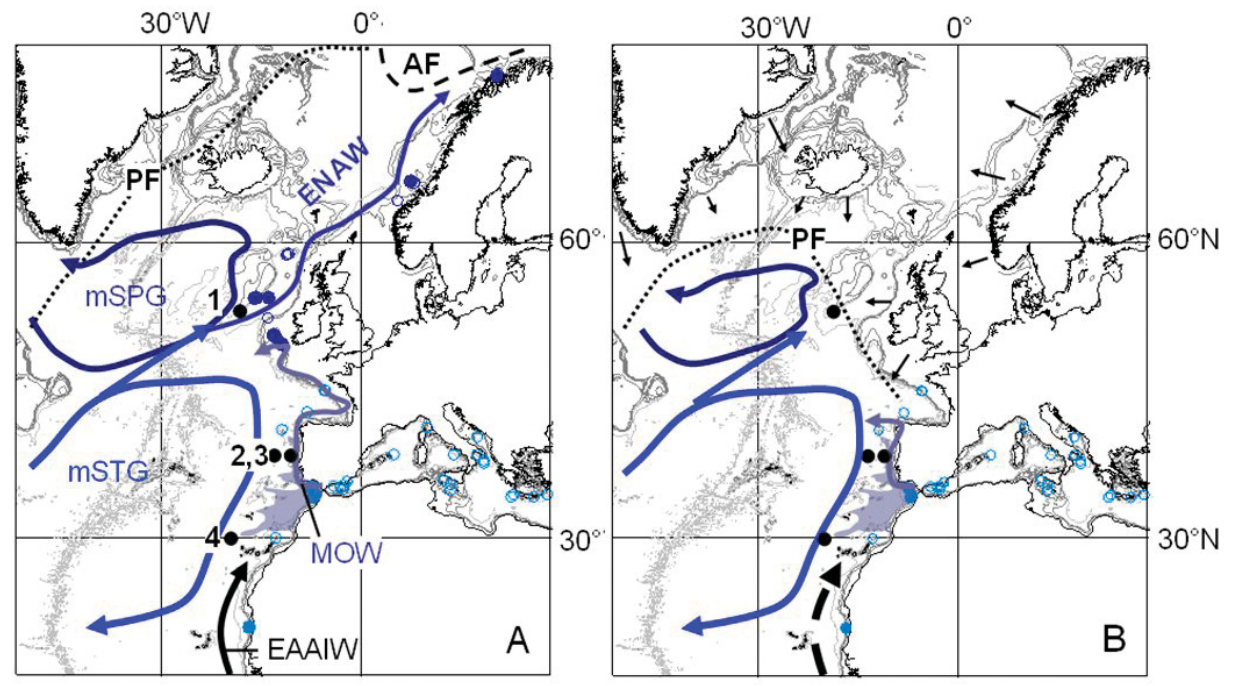

Figure 1. A: Location of fossil coral occurrences, sediment cores, and main water masses. Solid blue symbols - corals from coral carbonate mound sediments. Open blue symbolssurficial corals (dredge and remotely operated vehicle). Sea-surface temperature, icerafted debris, and productivity reconstructions (Fig. 2) from sediment cores (black dots): (1) GIK23414/5-9, (2) SU81-18, (3) D11957, (4) GIK15637-1 (for references, see footnote 1). Water masses: ENAW-Eastern North Atlantic Water; mSPG-mid-depth Subpolar Gyre; mSTG-mid-depth Subtropical Gyre; MOW-Mediterranean Outflow Water; EAAIW-East Antarctic Intermediate Water. Dashed lines: PF-polar front; AF-Arctic front. B: Same map as in A for periods of major Northern Hemisphere cooling, indicating southward displacement of PF (Eynaud et al., 2009) and disappearance of coral reefs to the north. Black arrows indicate discharge of icebergs to the North Atlantic. 
limit, closely linked to the oceanic polar front and Arctic front (Fig. 1A).

In the temperate East Atlantic (TEA), the flourishing boreal belt of cold-water corals turns into scattered coral populations with small local thickets. Corals occur on top of deep oceanic banks, along steep canyon walls, and on the flanks of seamounts. Active reef development comparable to the northern habitats has yet not been found in these regions. However, extended Pleistocene sedimentary coral accumulations have been discovered in the Gulf of Cadiz, along the Moroccan margin, and off Mauritania (Colman et al., 2005; Wienberg et al., 2009). In addition to the mid-depth water masses mentioned here, corals in these areas are exposed to the influence of Mediterranean Outflow Water and East Antarctic Intermediate Water, contributing to the middepth circulation (Fig. 1). Live corals dwell in higher water temperatures compared to those in the north $\left(10-12^{\circ} \mathrm{C}\right)$, at slightly lower oxygen levels of 3-4.3 $\mathrm{ml} \mathrm{L}^{-1}$ (Levitus Ocean Atlas 94, http://iridl.ldeo.columbia.edu/SOURCES/. LEVITUS94/.ANNUAL/.O2/) and presumably also at lower annual labile organic matter fluxes. Within canyon environments such as in the Mediterranean Sea, live corals (in particular Madrepora oculata) occur at even higher temperatures (to $15^{\circ} \mathrm{C}$ ), and abundances seem controlled by the availability of suitable hard substrate and currents (Orejas et al., 2009). Thus it is clear that many factors control the presence of cold-water corals in the mid-depth East Atlantic and Mediterranean.

In an attempt to reveal the large-scale pattern of decline and growth of such cold-water coral reefs throughout the past climate cycles, we have carried out a systematic study of the temporal coral age patterns in northern $\left(50^{\circ}-\right.$ $\left.70^{\circ} \mathrm{N}\right)$ and temperate regions $\left(20^{\circ}-50^{\circ} \mathrm{N}\right)$. The study reveals the coral's biogeographical distribution through time along the 6000-km-long European margin, influenced by large-scale oceanic and climate change affecting productivity, mid-depth temperatures, and sedimentary processes.

\section{METHODOLOGY}

We have applied a recently developed rapid age screening technology for ${ }^{230} \mathrm{Th} / \mathrm{U}$ dating of cold-water corals (Douville et al., 2010). In addition to the new dates from coral species Lophelia pertusa and Madrepora oculata, we compiled 324 dates from our previous work and the literature to provide for the first time a comprehensive overview about the long-term development of cold-water corals in the northeast Atlantic. These coral ages have been compiled from a large range of sediment cores in coral reef settings as well as from dredged material representing coral growth over the past three

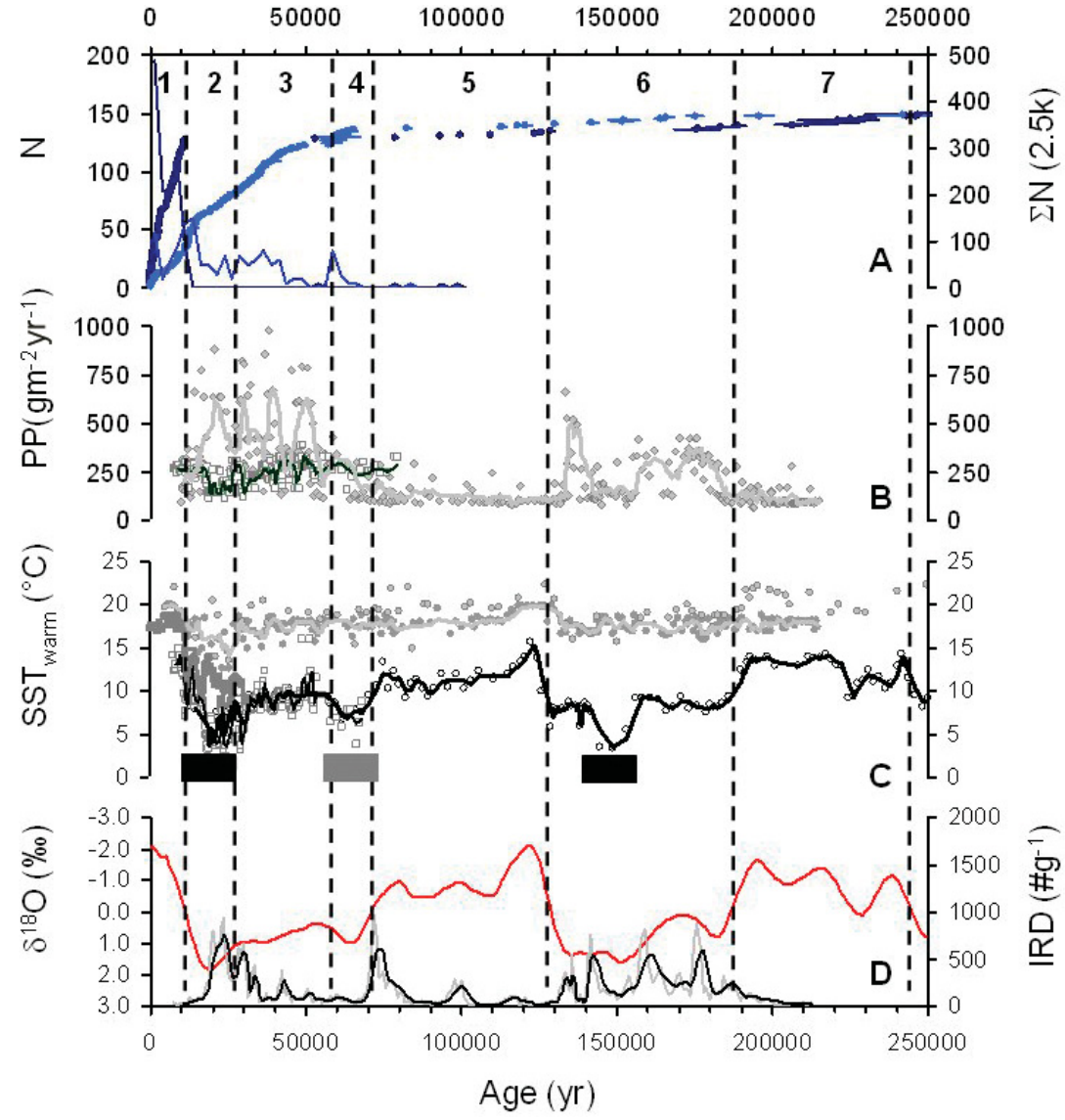

Figure 2. A: Number of ages of framework-forming cold-water corals (dark blue-northern East Atlantic; light blue-temperate East Atlantic, TEA, including Mediterranean Sea). Solid lines reflect sum of ages per 2500 yr for past 100 k.y. B: Primary productivity (PP) reconstructions for south of Rockall Bank (dark green-GIK23414/5-9) and for TEA (light gray-combined records of D11957 and GIK15637-1). C: Sea-surface temperature (SST) reconstructions for south of Rockall Bank (black line-GIK23414/5-9), and TEA (dark gray-SU81-182; light gray-D11957 and GIK15637-1). Black and gray boxes indicate SST decreases to $6{ }^{\circ} \mathrm{C}$. D: SPECMAP oxygen isotope record (red) (Imbrie et al., 1993), and ice-rafted debris (IRD) from sediment core GIK23414/5-9 south of Rockall Bank.

glacial-interglacial cycles (Figs. 1 and 2; see the GSA Data Repository ${ }^{1}$ for details).

\section{RESULTS AND DISCUSSION}

Age data obtained from coral-bearing sediments represent not only the timing of active coral growth, but also measures of vertical mound accumulation rates (Frank et al., 2009). Densely populated coral mounds at optimal growth conditions result in vertical mound accumulation rates $>30 \mathrm{~cm} \mathrm{k.y.}{ }^{-1}$, while relatively inactive or abandoned reefs yield rates of $<5 \mathrm{~cm} \mathrm{k.y.}{ }^{-1}$ (Frank et al., 2009). Most samples are studied from socalled "coral carbonate mounds," thus providing both the timing and rate of coral growth. However, our data set also includes numerous ages

${ }^{1}$ GSA Data Repository item 2011225, coral Useries age data and supplemental material on coldwater coral sites, is available online at www.geosociety.org/pubs/ft2011.htm, or on request from editing@geosociety.org or Documents Secretary, GSA, P.O. Box 9140, Boulder, CO 80301, USA. obtained on individual fossil corals recovered using dredges and remotely operated vehicles (ROVs), in particular for the Mediterranean Sea (McCulloch et al., 2010).

\section{Temperate East Atlantic Including the Bay of Biscay and Mediterranean Sea}

Coral ages from between $20^{\circ} \mathrm{N}$ and $50^{\circ} \mathrm{N}$, including numerous cold-water coral mounds (Eisele et al., 2011; Wienberg et al., 2010), reveal a continuous presence of corals over the past 45 k.y., and beyond scattered ages indicate coral occurrences during cold and warm climate periods (Marine Isotope Stages MIS 4, MIS 5, MIS 6, MIS 7, and MIS 8) (Fig. 2A). Thus, within the TEA, coral growth conditions have been favorable to sustain cold-water coral ecosystems over glacial-interglacial cycles, but the activity of the reef ecosystems strongly varies through time, with the development of framework-forming corals on mounds in the Gulf of Cadiz and off Mauritania occurring only 
during past glacial stages (Eisele et al., 2011; Wienberg et al., 2010). Overall, coral ages representing glacial and interstadial climate periods (Younger Dyras, MIS 2, MIS 3, MIS 4 , MIS 6, MIS 8) reflect $75 \%$ of the TEA data compilation, including the Mediterranean Sea, compared to $25 \%$ of ages from full interglacial climate periods (MIS 1, MIS 5). Moreover, the early to mid-Holocene coincides with a decline in the number of coral ages per $2500 \mathrm{yr}$ within the TEA (Fig. 2A), as would be expected from worsening environmental conditions related to climate warming of the Northern Hemisphere. In contrast, a reincreasing number of ages are found during the past $2500 \mathrm{yr}$, reflecting ages of fossil corals solely from the Bay of Biscay, the Galicia Bank, and the Mediterranean Sea. The temporal history of coral occurrence in those areas is, however, very difficult to access due to the patchy nature of coral occurrences in canyons and on banks (De Mol et al., 2011; Reveillaud et al., 2008). Those areas remain today largely underexplored, but reflect crucial transitional zones between both major coldwater coral reef provinces (Gulf of Cadiz and Porcupine Seabight), within which corals may occur at any time (De Mol et al., 2011), but in which mound-like structures are absent and fossil coral occurrences are strongly affected by erosion, glacial river drainage, sedimentation, and landslides (De Mol et al., 2009). Age data from the Mediterranean Sea (McCulloch et al., 2010) nicely complement the records obtained throughout the TEA, but the most recent period (0-2500 yr) seems overrepresented (potentially due to a sampling bias). This is because age data by McCulloch et al. (2010), as well as portions of our own data set, rely on dredged and ROV sampled surficial fossil corals, which may favor recovery of the most recent corals. However, most of the ages represent predominantly periods of Northern Hemisphere cooling, as for the other eastern temperate Atlantic sites. During periods of Northern Hemisphere cooling (glacial and interstadial climate periods), increases of productivity due to enhanced upwelling and modified nutrient availability occurred off Portugal, within the Gulf of Cadiz, and off Mauritania (Fig. 2B), potentially associated with a more important northward propagation of East Antarctic Intermediate Water. In addition, surface water temperatures decreased by as much as $4{ }^{\circ} \mathrm{C}$ off Portugal (MARGO Project Members, 2009) and by $<2{ }^{\circ} \mathrm{C}$ farther south (Fig. 2C), accompanied by southward displacements of the polar front (Eynaud et al., 2009). Cooling of mid-depth waters is thought to occur in the northern East Atlantic and TEA, but at a smaller amplitude compared to surface waters (Mignot et al., 2007). Overall, changes of environmental conditions alone do not seem to have been controlling factors for the sustainable development of cold-water corals in the TEA and Mediterranean Sea, but Northern Hemisphere cooling likely led to temperature ranges and food supply regimes being more similar there to conditions found today in the northern East Atlantic.

\section{North-East Atlantic Coral Age Records Between $50^{\circ}$ and $70^{\circ} \mathrm{N}$}

In contrast to the TEA, including the Mediterranean Sea and Bay of Biscay, the northern East Atlantic reveals a dramatically different record of coral ages. Over the past climatic cycles $94 \%$ of age data represents coral growth during full interglacial climate, and the remaining $6 \%$ is indicative of coral growth during colder, but not glacial, climate conditions (Fig. 2A). These later ages are associated with Northern Hemisphere warming within MIS 3 (Dorschel et al., 2005) or reflect potential MIS 8 growth of corals from a poorly resolved part of Thérèse and Challenger mounds (Porcupine Seabight). Overall coral growth and vertical coral mound accumulation during cold climate periods was insufficient to leave an accessible trace in the sedimentary record. After the last glacial period coral mounds became recolonized ca. $11.5 \mathrm{ka}$ and then developed profusely. Corals migrated farther north rapidly, based on accelerator mass spectrometer ${ }^{14} \mathrm{C}$ dating of $L$. pertusa corals from a reef at Stjernsund $\left(70^{\circ} 15^{\prime} \mathrm{N}, 20^{\circ} 29^{\prime} \mathrm{E}\right.$, 9190 yr calibrated B.P.) that developed directly on top of a submarine glacial moraine.

Before warm climate coral development, glacial environmental conditions thus clearly resulted in a dramatic reduction of coral abundance and growth at upper intermediate depths north of $50^{\circ} \mathrm{N}$ (Fig. 2A). Along the Norwegian margin reef growth is absent during glacial periods through the grounding and discharge of ice sheets (Ottesen et al., 2005). In addition, surface-water productivity (food supply) was reduced, and as the polar front migrated southward, surface and subsurface waters cooled by as much as $8{ }^{\circ} \mathrm{C}$ (MARGO Project Members, 2009). Sea-surface temperature (SST) and productivity from south of Rockall Bank, shown in Figures $2 \mathrm{~B}$ and $2 \mathrm{C}$, reveal three major periods of extreme cooling (SST drops below $5{ }^{\circ} \mathrm{C}$ ) during the Last Glacial Maximum, accompanied by a dramatic decrease in primary productivity $\left(<200 \mathrm{~g} \mathrm{~m}^{-2} \mathrm{yr}^{-1}\right)$ (Fig. 2C). Those coldest periods may have imposed critical temperature and food supply conditions on framework-forming cold-water corals in the northern East Atlantic. However, these periods of extreme cooling do not overlap entirely with the periods of absent coral ages. Thus, other factors must be important, such as ice sheet discharge of meltwater and sediments into the near coastal areas, as recorded by the ice-rafted debris record (Fig. 2D), that affect water-mass stratification, circulation patterns, and terrigenous sedimentation. During the deglaciations, the continental slopes are subject to strong erosion and potentially an increasing number of landslides (De Mol et al., 2009). In summary, the sustainable development of corals in the northern East Atlantic is clearly paced by Northern Hemisphere warming. However, the climate impact that turned profusely growing reefs into dead coral rubble is opposite of that in the TEA. In the TEA warming, declining food supply and other as-yet unknown local factors seem to impose a limit to the prosperous growth of cold-water coral reefs. In contrast, in the northern East Atlantic, cooling and food supply as well as terrigenous sedimentation limit the glacial growth of cold-water corals. Thus while overall coral carbonate mound development is locally affected by many sitespecific hydrodynamic processes (White and Dorschel, 2010) not discussed here, it seems from comparison of coral age records with sedimentary records along the European margin that mid-depth temperatures and primary productivity may play crucial roles as drivers of those coral ecosystems. However, despite its importance, little is known about changes in middepth temperatures.

In summary, our age data clearly demonstrate that the biogeographical limit of reef framework-forming cold-water coral ecosystems oscillated between $\sim 50^{\circ} \mathrm{N}$ and $\sim 70^{\circ} \mathrm{N}$, controlled by the ice age cycles, and those oscillations may follow the temporal variations of the polar front as prominent changes in temperature, productivity, and ocean dynamics reflect the movement of the polar front in the eastern Atlantic. However, in the TEA corals survive dramatic climate change, with active coral growth even in the relatively warm recesses of the Mediterranean Sea (McCulloch et al., 2010). Given that the TEA always sustains coral growth, it is tempting to assume that coral larvae are transported along with the northward-moving currents, such as Mediterranean Sea Water, as suggested by De Mol et al. (2005). The future expected ocean warming and reduced sea ice cover in the Arctic Ocean might be expected to promote a further northward invasion of framework-forming cold-water coral ecosystems into the Arctic Ocean. However, the rapid predicted shallowing of the aragonite saturation depth in light of anthropogenic ocean acidification, in particular in the Arctic Ocean, may limit the ability of corals to calcify (Maier et al., 2009; Orr et al., 2005). It is therefore possible that anthropogenic climate change may prevent this northward expansion, since ocean warming, acidification, and altered circulation and food supply regimes may impede coral growth from the temperate Atlantic to the Norwegian margin. Thus, ocean warming and circulation changes, together with other anthropogenic influences such as ocean acidification and deep trawling, 
may radically change the occurrence and distribution of reef framework-forming coral habitats in the future.

\section{ACKNOWLEDGMENTS}

This research was funded through European Union grants (projects HERMES, HERMIONE, and EPOCA: GOCE-CT-2005-511234-1, 226354, 211384 and European Science Foundation Microsystems, and Carbonate) and through the French Commissariat à l'Énergie Atomique et aux Énergies Alternatives, the Centre National de la Recherche Scientifique, and a grant from the Agence Nationale de la Recherche (ANR NEWTON: BLANC06-1-139504). We acknowledge the support of Institut Polaire Français and shipboard scientific parties. We thank three anonymous reviewers for helpful comments. This is Laboratoire des Sciences du Climat et de l'Environnement contribution 4511.

\section{REFERENCES CITED}

Colman, J.G., Gordon, D.M., Lane, A.P., Forde, M.J., and Fitzpatrick, J.J., 2005, Carbonate mounds off Mauritania, northwest Africa: Status of deep-water corals and implications for management of fishing and oil exploration activities, in Freiwald, A., and Roberts, J.M., eds., Cold-water corals and ecosystems: Heidelberg, Springer, p. 417-441.

Davies, A.J., Wisshak, M., Orr, J.C., and Roberts, J.M., 2008, Predicting suitable habitat for the cold-water coral Lophelia pertusa (Scleractinia): Deep-Sea Research, v. 55, Part I, p. 1048-1062, doi:10.1016/j.dsr.2008.04.010.

Davies, A.J., Duineveld, G., Lavaleye, M., Bergman, M., van Haren, H., and Roberts, J.M., 2009, Downwelling and deep-water bottom currents as food supply mechanisms to the coldwater coral Lophelia pertusa (Scleractinia) at the Mingulay Reef Complex: Limnology and Oceanography, v. 54, p. 620-629, doi:10.4319/ lo.2009.54.2.0620.

De Mol, B., Henriet, J.P., and Canals, M., 2005, Development of coral banks in Porcupine Seabight: Do they have Mediterranean ancestors?, in Freiwald, A., and Roberts, J.M., eds., Cold-water corals and ecosystems: Heidelberg, Springer, p. 515-533.

De Mol, B., Huvenne, V., and Canals, M., 2009, Coldwater coral banks and submarine landslides: A review: International Journal of Earth Sciences, v. 98, p. 885-899, doi:10.1007/s00531 $-008-0372-6$.

De Mol, L., Van Rooij, D., Pirlet, H., Greinert, J., Frank, N., Quemmerais, F., and Henriet, J.P., 2011, Coldwater coral habitats in the Penmarc'h and Guilvinec Canyons (Bay of Biscay): Deep-water versus shallow-water settings: Marine Geology, v. 282, p. 40-52, doi:10.1016/j.margeo.2010.04.011.

Dorschel, B., Hebbeln, D., Rüggeberg, A., Dullo, W.-C., and Freiwald, A., 2005, Growth and erosion of a cold-water coral covered carbonate mound in the Northeast Atlantic during the late Pleistocene and Holocene: Earth and Planetary Science Letters, v. 233, p. 33-44, doi:10.1016/j .eps1.2005.01.035.

Douville, E., Salle, E., Frank, N., Eisele, M., PonsBranchu, E., and Ayrault, S., 2010, Rapid and precise ${ }^{230} \mathrm{Th} / \mathrm{U}$ dating of ancient carbonates using inductively coupled plasma-quadrupole mass spectrometry: Chemical Geology, v. 272, p. 1-11, doi:10.1016/j.chemgeo.2010.01.007.

Dullo, W.-C., Flögel, S., and Rüggeberg, A., 2008, Cold-water coral growth in relation to the hydrography of the Celtic and Nordic European continental margin: Marine Ecology Progress Series, v. 371 , p. 165-176, doi:10.3354/ meps07623.

Eisele, M., Frank, N., Wienberg, C., Hebbeln, D., Lopez Correa, M., Douville, E., and Freiwald, A., 2011, Productivity controlled cold-water coral growth periods during the last glacial off Mauritania: Marine Geology, v. 280, p. 143149, doi:10.1016/j.margeo.2010.12.007.

Eynaud, F., de Abreu, L., Voelker, A., Schönfeld, J., Salgueiro, E., Turon, J.L., Penaud, A., Toucane, S., Naugthon, F., Sanchez-Goni, M., Malaize, B., and Cacho, I., 2009, Position of the Polar Front along the western Iberian margin during key cold episodes of the last $45 \mathrm{ka}$ : Geochemistry Geophysics Geosystems, v. 10, p. 1-21, doi:10.1029/2009GC002398.

Frank, N., Ricard, E., Lutringer-Paquet, A., van der Land, C., Colin, C., Blamart, D., Foubert, A., Van Rooij, D., Henriet, J.-P., de Haas, H., and van Weering, T., 2009, The Holocene occurrence of cold water corals in the NE Atlantic: Implications for coral carbonate mound evolution: Marine Geology, v. 266, p. 129-142, doi:10.1016/j.margeo.2009.08.007.

Freiwald, A., 2002, Reef-forming cold-water corals, in Wefer, G., et al., eds., Ocean margin systems: Berlin, Heidelberg, Springer, p. 365-385.

Imbrie, J., and 18 others, 1993, On the structure and origin of major glaciation cycles 2: The 100,000-year cycle: Paleoceanography, v. 8 , p. 699-735.

Maier, C., Hegeman, J., Weinbauer, M.G., and Gattuso, J.-P., 2009, Calcification of the cold-water coral Lophelia pertusa under ambient and reduced pH: Biogeosciences, v. 6, p. 1671-1680, doi:10.5194/bg-6-1671-2009.

MARGO Project Members, 2009, Constraints on the magnitude and patterns of ocean cooling at the Last Glacial Maximum: Nature Geoscience, v. 2, p. 127-132, doi:10.1038/ngeo411.

McCulloch, M., Taviani, M., Montagna, P., López Correa, M., Remia, A., and Mortimer, G., 2010, Proliferation and demise of deep-sea corals in the Mediterranean during the Younger Dryas: Earth and Planetary Science Letters, v. 298, p. 143-152, doi:10.1016/j.epsl.2010.07.036.
Mignot, J., Ganopolski, A., and Levermann, A., 2007, Atlantic subsurface temperatures: Response to a shutdown of the overturning circulation and consequences for its recovery: Journal of Climate, v. 20, p. 4884-4898, doi:10.1175/JCLI4280.1.

Orejas, C., Gori, A., Lo Iacono, L., Puig, P., Gili, J.F., and Dale, M.R.T., 2009, Cold-water corals in the Cap de Creus canyon, northwestern Mediterranean: Spatial distribution, density and anthropogenic impact: Marine Ecology Progress Series, v. 397, p. 37-51, doi:10.3354/ meps08314.

Orr, J.C., and 27 others, 2005, Anthropogenic ocean acidification over the twenty-first century and its impact on calcifying organisms: Nature, v. 437, p. 681-686.

Ottesen, D., Rise, L., Knies, J., Olsen, L., and Henriksen, S., 2005, The Vestfjorden-Traenadjupet paleo-ice stream drainage system, mid-Norwegian continental shelf: Marine Geology, v. 218, p. 175-189, doi:10.1016/j.margeo.2005.03.001.

Reveillaud, J., Freiwald, A., Van Rooij, D., Le Guilloux, E., Altuna, A., Foubert, A., Vanreusel, A., Olu. K., and Henriet, J., 2008, The distribution of scleractinian corals in the Bay of Biscay, NE Atlantic: Facies, v. 54, p. 317-331, doi: 10.1007/s10347-008-0138-4.

Roberts, J.M., Wheeler, A.J., Freiwald, A., and Cairns, S., 2009, Cold-water corals: The biology and geology of deep-sea coral habitats: Cambridge, Cambridge University Press, $334 \mathrm{p}$.

Roberts, J.M., Wheeler, A.J., and Freiwald, A., 2006, Reefs of the deep: The biology and geology of deep-water coral ecosystems: Science, v. 312, p. 543-547, doi:10.1126/science.1119861.

White, M., and Dorschel, B., 2010, The importance of the permanent thermocline to the cold water coral carbonate mound distribution in the NE Atlantic: Earth and Planetary Science Letters, v. 296, p. 395-402, doi:10.1016/j.epsl 2010.05.025.

Wienberg, C., Hebbeln, D., Fink, H.G., Mienis, F., Dorschel, B., Vertino, A., López Correa, M., and Freiwald, A., 2009, Scleractinian coldwater corals in the Gulf of Cádiz-First clues about their spatial and temporal distribution: Deep-Sea Research I, v. 56, p. 1873-1893, doi:10.1016/j.dsr.2009.05.016.

Wienberg, C., Frank, N., Mertens, K.N., Stuut, J.B., Marchant, M., Fietzke, J., Mienis, F., and Hebbeln, D., 2010, Glacial cold-water coral growth in the Gulf of Cádiz: Implications of increased palaeo-productivity: Earth and Planetary Science Letters, v. 298, p. 405-416, doi:10.1016/j .eps1.2010.08.017.

Manuscript received 14 October 2010

Revised manuscript received 10 March 2011

Manuscript accepted 15 March 2011

Printed in USA 